\title{
A MODEL OF CONTAINER TRANSSHIPMENT PORT COMPETITION: AN EMPIRICAL STUDY OF INTERNATIONAL PORTS IN TAIWAN
}

\author{
Wen-Chih Huang \\ Department of Regional Development and Management, Leader University, Tainan, Taiwan, R.O.C. \\ Hsu-Hsi Chang \\ CECI Engineering Consultants, Inc.,Taipei, Taiwan, R.O.C., sschang@ceci.com.tw \\ Ching-Tsyr Wu \\ Department of Harbor and River Engineering, National Taiwan Ocean University, Keelung, Taiwan, R.O.C.
}

Follow this and additional works at: https://jmstt.ntou.edu.tw/journal

Part of the Business Commons

\section{Recommended Citation}

Huang, Wen-Chih; Chang, Hsu-Hsi; and Wu, Ching-Tsyr (2008) "A MODEL OF CONTAINER TRANSSHIPMENT PORT COMPETITION: AN EMPIRICAL STUDY OF INTERNATIONAL PORTS IN TAIWAN," Journal of Marine Science and Technology: Vol. 16: Iss. 1, Article 3.

DOI: $10.51400 / 2709-6998.1993$

Available at: https://jmstt.ntou.edu.tw/journal/vol16/iss1/3

This Research Article is brought to you for free and open access by Journal of Marine Science and Technology. It has been accepted for inclusion in Journal of Marine Science and Technology by an authorized editor of Journal of Marine Science and Technology. 


\section{A MODEL OF CONTAINER TRANSSHIPMENT PORT COMPETITION: AN EMPIRICAL STUDY OF INTERNATIONAL PORTS IN TAIWAN}

\section{Acknowledgements}

The authors would like to thank Institute of Transportation Ministry of Transportation and Communications for its support of the research MOTC-IOT-95- H1DB003. The content of this paper is part of the results from that study. 


\title{
A MODEL OF CONTAINER TRANSSHIPMENT PORT COMPETITION: AN EMPIRICAL STUDY OF INTERNATIONAL PORTS IN TAIWAN
}

\author{
Wen-Chih Huang *, Hsu-Hsi Chang **, and Ching-Tsyr Wu ***
}

Key words: PTC model, hub-and-spoke networks, transshipment container, hub port.

\begin{abstract}
The purpose of this study is to establish a model of transshipment port competition in order to understand container carriers' transshipment port selection. Accompanied by the enlargement of containership, the hub-and-spoke network is developed due to the economic consideration of containership routes. In between the feeder port and hub port, the production and attraction relationship can be existed. For pursing the maximum benefit, the carriers will choose the better hub port for their container transshipment base. Based on this assumption the authors established the "Port Container Transshipment Competition Model (PTC Model)" to conduct the empirical study on Taiwan international ports which coincides with observed data.
\end{abstract}

\section{INTRODUCTION}

In '90, the high transportation cost has forced the Post-Panamax size ships joined the operation, their capacity are in the range of 5,000 6,000 TEU. However, these ships can not pass through the Panama Canal due to the large draft and can only dock on the deep water port. Gradually, the pendulum services dominate the major container liner routes and the hub-and-spoke networks were formed. In these networks the transshipment ports were selected as collecting centers for cargos from feeder ports and inland transport. Besides the service routes, carriers also adapt the large containerships to reduce their unit transportation cost and increases their competitiveness. It is why in this decade the containership continuously grows bigger and it is estimated the containership will grow to

Paper submitted 11/16/06; accepted 02/26/07. Author for correspondence: Hsu-Hsi Chang (e-mail: sschang@ceci.com.tw).

* Department of Regional Development and Management, Leader University, Tainan, Taiwan, R.O.C.

** CECI Engineering Consultants, Inc.,Taipei, Taiwan, R.O.C.

*** Department of Harbor and River Engineering, National Taiwan Ocean University, Keelung, Taiwan, R.O.C.
18,000 TEU. That's why Ashar [1] forecasted the final routes in the future will be composite of three major routes, namely: the "Equatorial Round the World", the "North/South Trade" and the "Regional Feeder Services". And in the "Equatorial Round the World" route the large containership will only dock on 7 pure transshipment ports and containers should transport from regional center and feeder port by small feeder liner. However, the actualization of "Equatorial Round the World" route is still uncertain due to many variations; for example, one of them is the completion of Panama Canal expansion project.

According to the development of hub-and-spoke network, the container port can be divided into three categories: hub port, trunk port and feeder ports. In Pacific Asia region there are 5 Hub ports, which are Singapore, Hong Kong, Kaohsiung, Busan and Tanjung Pelepas (see Fig. 1). As showing in Table 1, in 2005, the ratio of transshipment container and container throughput for these five ports are all over $40 \%$. Singapore port handles the highest transshipment volume, 18.79 millions TEU, equivalent to $81 \%$ of throughput volume. The second highest is Hong Kong, which handles 10.15 millions TEU of transshipment container equivalent to $44.9 \%$ of container throughput. The third is Busan port, the transshipment volume is 5.18 million TEU and ratio is $43.7 \%$. The fourth is Kaohsiung port, the transshipment volume is 4.82 million TEU and ratio is $50.9 \%$. The fifth is Tanjung Pelepas port, the transshipment volume is 4 million TEU and ratio is $96 \%$. Although the container throughput for Shanghai port and Shenzhen port already over 10 millions TEU, but their transshipment volume are only 0.40 millions TEU and 1.30 millions TEU, the ratio are lower than $10 \%$. It is why Shanghai port and Shenzhen port can not be called hub port.

Accompanied by the prevalence of hub-and-spoke networks, almost every country invests their port facility continuously and tries to develop their port into a hub port. The severe competition in ports has attracted scholars interesting and started to discuss this issue. For example, Robinson [17] studied the history of containership development and generalized the ports and maritime transport network evolution in Far East region, and concluded that the hub-and-spoke networks in Fast East region will evolve continuously based on their operational cost and efficiency. Bendall and Stent [2] used the hub-and-spoke networks to structure the scheduling service for high speed con- 
Table 1. The transshipment volume of main ports in Asia-Pacific area (2005).

\begin{tabular}{l|c|c|c|c}
\hline \multicolumn{1}{c|}{ Port } & Region & $\begin{array}{c}\text { Total } \\
\text { Throughput } \\
\text { (Million TEU) }\end{array}$ & $\begin{array}{c}\text { Transshipment } \\
\text { Estimate } \\
\text { (Million TEU) }\end{array}$ & $\begin{array}{c}\text { Estimate } \\
\text { Transshipment } \\
\text { Incidence }\end{array}$ \\
\hline Singapore & SE Asia & 23.19 & 18.79 & $81.0 \%$ \\
\hline Hong Kong & Far East & 22.60 & 10.15 & $44.9 \%$ \\
\hline Busan & Far East & 11.84 & 5.18 & $43.7 \%$ \\
\hline Kaohsiung & Far East & 9.47 & 4.82 & $50.9 \%$ \\
\hline Tanjung Pelepas & SE Asia & 4.17 & 4.00 & $96.0 \%$ \\
\hline
\end{tabular}

Source: $[5,6,12]$.

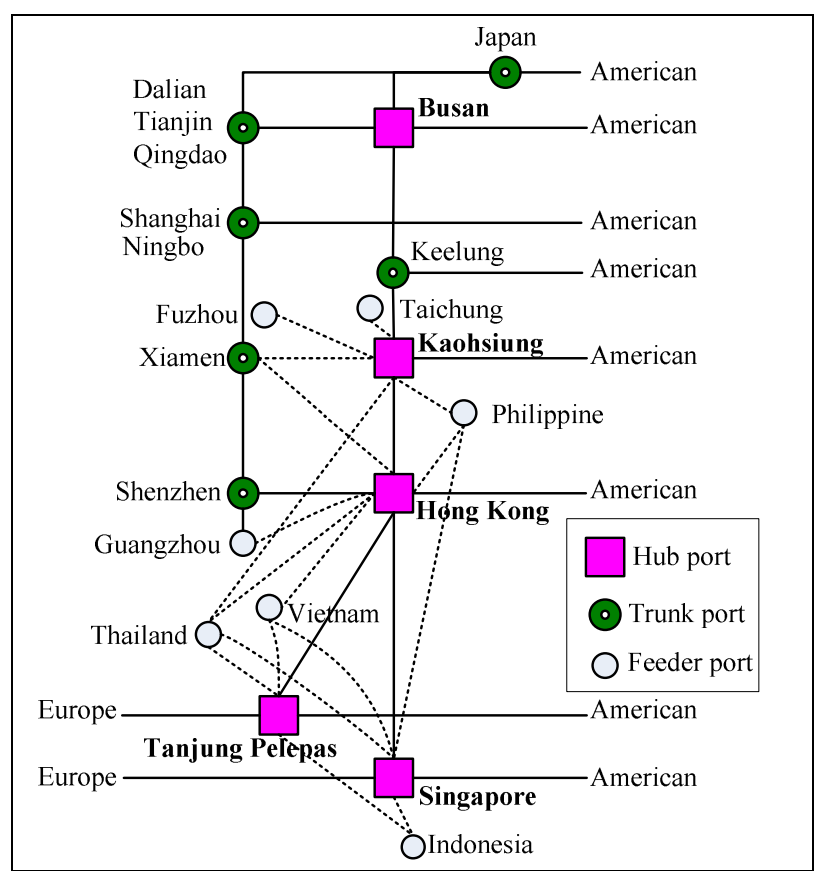

Fig. 1. The development of hub-and-spoke network in Asian ports.

tainer ship and short sea service. Mourão, Pato and Paixão [14] structured the ship assignment model for hub-and-spoke networks and in the model limitation conditions were used to deal with the transshipment characteristic. O'Kelly $[15,16]$ used the geographic development of aeronautic hub-and-spoke networks to analyze the location of hub port and assignment of feeder ports. Kuroda and Yang [13] separated the port transportation system into three categories, namely: government, carrier, shipper, and introduced the concept of Stackelberg Game to buildup a mathematic model and forecasted the container volume in the ports of Asia Pacific Region. Hsieh and Wong [7] applied the quadratic assignment in integer programming to establish the maximal profit model for hub port and feeder port to select and configure their locations. Hsu and Hsieh [8] formulated a two-objective model by minimizing the shipping costs and inventory costs independently to select the route whether through a hub or directly to its destination. Huang et al.
$[9,10,11]$ applied the Multi-Criteria Decision Making (MCDM) methods including Analytic Hierarchy Process (AHP), Grey Relational Analysis (GRA) and fuzzy multi-criteria grade classification model to assess port competitiveness. Chang and Huang [3] established a Quantified SWOT (Strengths, Weaknesses, Opportunities and Threats) method to analyze the competitiveness of East Asia port in pursuing the transshipment containers.

Accompanied by the enlargement of containership, the hub-and-spoke network is developed due to the economic consideration of containership routes. In between the feeder port and hub port, the production and attraction relationship can be existed. For pursing the maximum benefit, the carriers will choose the better hub port for their container transshipment base. Based on this characteristic, the authors combined the quantified SWOT method and integer programming method to establish the Port Container Transshipment Competition Model (PTC model) to analyze the competition of container transshipment in different ports and applied this on the Taiwan international ports.

\section{MODEL FORMULATION}

Generation of container transshipment is the result of hub-and-spoke networks planning by carrier; and choosing the best transshipment center location, carriers certainly will pursue center's maximum utility. Considering the income maximization, container carriers will service the import/export cargo firstly, and only if there are extra capacities transshipment container will be served. From above explanation, "utility of maritime transport cost", "utility of transshipment port cost" and "utility of hub port operation" will be the three main consideration factors for ship liner selecting the hub port. Based on the above theory, "quantified SWOT" and "integer programming" were combined to form a mathematical model called the PTC model.

\section{Model Assumptions}

(1) Carrier is risk neutral and will pursue the maximum utility which means the gradient of utility function is fixed.

(2) The routes and ship lines are known.

(3) The volume of origin port and destination port are known. 
(4) Carrier will serve the import/export container first before serve the transshipment container.

\section{PTC Model}

$$
\begin{aligned}
\operatorname{Max} . U= & w_{1} \sum_{i}^{n} \sum_{j}^{m} U_{i j}^{c} X_{i j}+w_{2} \sum_{j}^{m} \sum_{k}^{l} U_{j k}^{c} X_{j k} \\
& +w_{3} \sum_{i}^{n} \sum_{j}^{m} C F_{i j}\left(U_{i j}^{p}+S W_{i j}+O T_{i j}\right) Y_{i j} \\
& +w_{4} \sum_{j}^{m} \sum_{k}^{l} C F_{j k}\left(U_{j k}^{p}+S W_{j k}+O T_{j k}\right) Y_{j k}
\end{aligned}
$$

Subject to

$$
\begin{array}{cc}
\sum_{j=1}^{m} Y_{i j} \leq S_{i} & i=1,2, \ldots, n \\
\sum_{j=1}^{m} Y_{j k}=D_{k} & k=1,2, \ldots, l \\
\sum_{i=1}^{n} Y_{i j}=\sum_{k=1}^{l} Y_{j k} & j=1,2, \ldots, m \\
\sum_{i=1}^{n} X_{i j}=\sum_{i=1}^{n} Y_{i j} & j=1,2, \ldots, m \\
\sum_{j=1}^{m} X_{j k}=\sum_{j=1}^{m} Y_{j k} & k=1,2, \ldots, l \\
\sum_{i=1}^{n} Y_{i j}+\sum_{k=1}^{l} Y_{j k} \leq M_{j} & j=1,2, \ldots, m \\
X_{i j} \leq L_{i j} & \forall i, j \\
X_{j k} \leq L_{j k} & \forall j, k \\
X_{j k}, Y_{i j}, Y_{j k} \geq 0 & \text { and integer } \forall i, j, k
\end{array}
$$

Where

$X_{i j}$ : Maritime volume of transshipment container from origin port $i$ to transshipment port $j$;

$X_{j k}$ : Maritime volume of transshipment container from transshipment port $j$ to destination port $k$;

$Y_{i j}$ : Unloading volume of transshipment container from origin port $i$ to transshipment port $j$;

$Y_{j k}$ : Loading volume of Transshipment container from transshipment port $j$ to destination port $k$;

$U_{i j}^{c}:$ Utility value of $C_{i j}$;

$$
U_{i j}^{c}=\frac{\min _{j} C_{i j}}{C_{i j}} \quad \forall i
$$

$C_{i j}$ : Maritime cost of transshipment container from origin port $i$ to transshipment port $j$;

$U_{j k}^{c}:$ Utility value of $C_{j k}$;

$$
U_{j k}^{c}=\frac{\min _{j} C_{j k}}{C_{j k}} \quad \forall k
$$

$C_{j k}$ :Maritime cost of transshipment container from transshipment port $j$ to destination port $k$;

$U_{i j}^{p}$ : Utility value of $P_{i j}$;

$$
U_{i j}^{p}=\frac{\min _{j} P_{i j}}{P_{i j}} \quad \forall i
$$

$P_{i j}$ : Unloading cost of transshipment container from origin port $i$ to transshipment port $j$;

$U_{j k}^{p}:$ Utility value of $P_{j k}$;

$$
U_{j k}^{p}=\frac{\min _{j} P_{j k}}{P_{j k}} \quad \forall k
$$

$P_{j k}$ : Loading cost of transshipment container from transshipment port $j$ to destination port $k$;

$S W_{i j}$ : Strengths and weaknesses utility value of transshipment port $j$ for container transship from origin port $i$ to transshipment port $j$;

$S W_{j k}$ : Strengths and weaknesses utility value of transshipment port $j$ for container transship from transshipment port $j$ to destination port $k$;

$O T_{i j}$ : Opportunity and threat utility value of transshipment port $j$ for container transship from origin port $i$ to transshipment port $j$;

$O T_{j k}$ : Opportunity and threat utility value of transshipment port $j$ for container transship from transshipment port $j$ to destination port $k$;

$C F_{i j}$ : Calibration value of transshipment port $j$ for container transship from origin port $i$ to transshipment port $j$;

$C F_{j k}$ : Calibration value of transshipment port $j$ for container transship from transshipment port $j$ to destination port $k$;

$S_{i}$ : Supply volume of container for origin port $i$;

$D_{k}$ : Demand volume of container for destination port $k$;

$M_{j}$ : Loading/unloading capacity of container for transshipment port $j$;

$L_{i j}$ : Carrier's transport capacity from origin port $i$ to transshipment port $j$;

$L_{j k}$ : Carrier's transport capacity from transshipment port $j$ to destination port $k$;

$w_{f}$ : Main item's weight for selecting the transshipment port.

$$
\begin{aligned}
& \sum_{f}^{4} w_{f}=1 \\
& 0<w_{f}<1 \quad \forall f
\end{aligned}
$$


The objective function (1) states that pursuing the maximum utility is the objective function for ship liners to select the location of transshipment port, and the factors in their consideration include: (i) the utility of maritime cost from origin port $i$ to transshipment port $j$; (ii) the utility of maritime cost from transshipment port $j$ to destination port $k$; (iii) the utility of operation for transshipment port $j$ when container transship from origin port $i$ to transshipment port $j$; (iv) the utility of operation for transshipment port $j$ when container transship from transshipment port $j$ to destination port $k$.

Constraint (2) is the constraint condition for container supply, it also means that the transshipment volume from origin port $i$ to transshipment port $j$ must be smaller than the total supply volume of origin port $i$. Constraint (3) is the constraint condition of demand, it means that the transship container volume from transshipment port $j$ to destination port $k$ must be equal to the demand of container $k$. Constraint (4) is the constraint condition for transportation conservation, it means that the transship volume from origin port $i$ to transshipment port $j$ must be equal to volume from transshipment $j$ to destination port $k$. Constraint (5) is the constraint condition for transportation conservation, it means the transship volume from origin port $i$ to transshipment port $j$ must be equal to the unloading volume at port $j$. Constraint (6) is also the constraint condition for transportation conservation, it means the transship volume from transshipment port $j$ to destination port $k$ must be equal to the loading volume at port $j$. Constraint (7) is the constraint condition for port $j$ loading/unloading capacity, it means the loading/unloading volume at transshipment port $j$ must be smaller than or equal to its capacity. Constraint (8) is the constraint condition of carriers' capacity, it means the transship volume from origin port $i$ to transshipment port $j$ must be smaller than or equal to carriers' capacity. Constraint (9) is also the constraint condition of carriers' capacity, it means the transship volume from transshipment port $j$ to destination port $k$ must be smaller than or equal to ship liners' capacity. Constraint (10) is the constraint condition for transshipment volume and loading/unloading volume must be integer.

\section{Quantified SWOT analytical method}

The quantified SWOT analytical method consists of the following six steps:

Step 1: Decide what's to be compared. For example: port A and $B$ etc.

Step 2: Research and draft the key factors of internal and external assessment to build a hierarchical structure.

Step 3: Collect data, reading to collect the objective and quantified performance (e.g., operating income) of the objects compared.

Step 4: Questionnaire investigation which includes 2 parts: one to investigate the weights of key factors using the AHP method; and the other to investigate the subjective quality performance (e.g., service quality of the shop assistants) of the compared objects.

In this paper, weights of internal and external assessment weights are proposed to be the same. Weights of key factors are obtained by using the AHP method that was proposed by Saaty [18]. Its aim is to systemize complicated problems and to solve them at different levels and aspects. A proportion scale of 1 , $2, \ldots, 9$ is used to show the comparison of all the weights to build a matrix; then find out the strength vector by eigenvalue solution which is often used in numerical analysis; finally, the relative weights of key factors can be obtained after the consistency test.

Step 5: Normalize the performance. Performance of all the key factors includes quantified performance that is an actual statistic (e.g., business volume) and qualified performance that is a score of subjective scoring of the questionnaire (e.g., 1 5 points). The aim of normalization is to unify the scales of the key factors. Here is a suggested normalization method [4]:

(1) Benefit-criteria normalization (the higher the better)

$$
r_{i j}=\frac{p_{i j}}{\max _{j} p_{i j}}
$$

(2) Cost-criteria normalization (the lower the better)

$$
r_{i j}=\frac{\min _{j} p_{i j}}{p_{i j}}
$$

Step 6: Calculate the internal and external weight score of the comparing object separately (normalization performance $\times$ weights).

\section{EMPIRICAL ANALYSES}

In this paper, the international ports in Taiwan are chosen as an example to be analyzed in the model.

\section{Analysis of Taiwan ports' container transshipment}

The total container transshipment volume for Taiwan area in 2005 is 5,244 thousand TEU. Kaohsiung port has the highest volume 4,817 thousand TEU which is $91.9 \%$ of Taiwan total transshipment volume. The second is the Taichung port has 316 thousand TEU (6.0\%). And the last is Keelung port has 111 thousand TEU (2.1\%). Observing the last 10 years (1996 2005) occupancy rate, most container transshipment volume is concentrated in Kaohsiung port, yearly average rate is $90.9 \%$. The second one is Taichung port $(6.1 \%)$, and then is Keelung port (3.1\%). In the mean time in 1999, Kaohsiung port's container transshipment volume is over its import/export volume, showing that Kaohsiung port has gradually exerting its functions as maritime transshipment center.

\section{Analysis of origin-destination (OD) for container transshipment}

In order to differentiate the major container transshipment market for Taiwan ports, this study follows each port OD sta- 


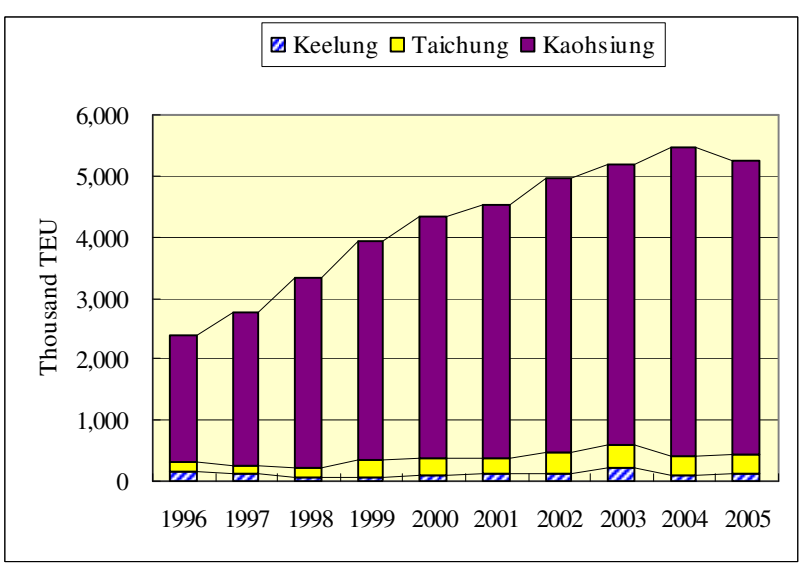

Fig. 2. Container transshipment volume for Taiwan ports (1996 2005).

tistic data and separate the market into 17 different regions, namely: Japan, Korea, Hong Kong, China (Minjiang area), Thailand, Malaysia, Singapore, Philippine, Indonesia, Southern Asia, Middle East, Other areas in Asia, Africa, North American, Latin American, Oceania and Europe regions, to conduct this OD analysis.

(1) Inward Transshipment

The total throughput of inward transshipment for Taiwan in 2005 is 2,322 thousand TEU, and according to Fig. 3 the volume from the front six regions are North American (15.1\%), China (14.1\%), Japan (12.4\%), Philippine (9.5\%), other areas in Asia (7.7\%) and Indonesia (7.6\%).

The throughput of Keelung port's inward transshipment is about 52 thousand TEU, among them $39.0 \%$ from Japan, $20.3 \%$ from Korea, $10.4 \%$ from other areas of Asia and $7.1 \%$ from Philippine. However, there is almost no transshipment container from Europe, it indicates that the major inward transshipment regions for Keelung port is Far East areas and falls into North/South trade route.

The throughput of Taichung port's inward transshipment is about 131 thousand TEU, among them $49.9 \%$ from Japan, $23.6 \%$ from Indonesia, 9.7\% from Korea, 5.9\% from Malaysia and $4.7 \%$ from other areas of Asia. However, there is no transshipment container from Latin America, Oceania and Europe, it indicates that the major transshipment routes for Taichung port is North/South trade route, the same as Keelung port.

The throughput of Kaohsiung port's inward transshipment is about 2,139 thousand TEU, among them $16.3 \%$ from North America, $15.3 \%$ from China, $10.1 \%$ from Philippine, $8.0 \%$ from Thailand, $9.5 \%$ from Japan, $7.8 \%$ from other areas of Asia, $6.5 \%$ from Hong Kong and $4.4 \%$ from Europe. The statistic data shows that despite the Far East and Southeast region, the Kaohsiung port's transshipment also coming from Europe and North America regions. It indicates that Kaohsiung is a very import transshipment center for Asia-Pacific region.

(2) Outward transshipment

The total throughput of outward transshipment for Taiwan

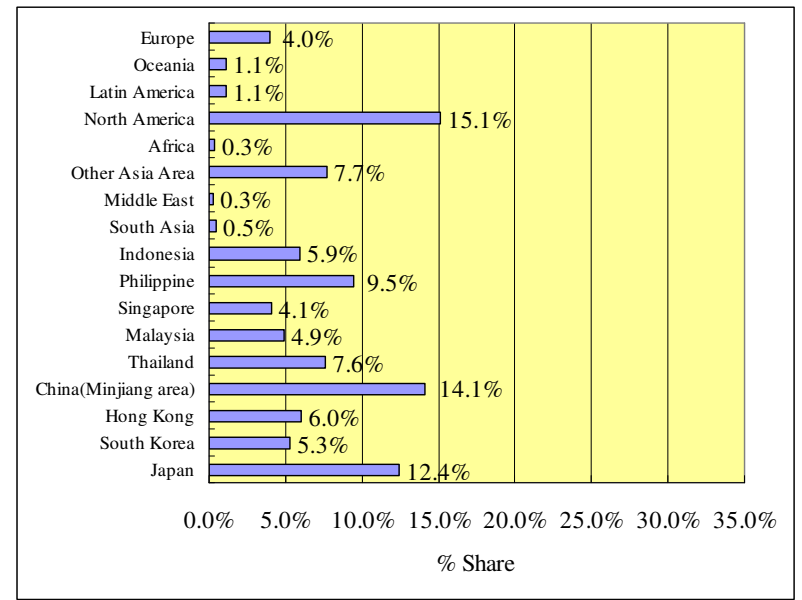

Fig. 3. Taiwan container throughput of inward transshipment from each region (2005).

in 2005 is 2,322 thousand TEU, and according to Fig. 4 the volume from the front six regions are North American (31.8\%), Japan (11.7\%), Philippine (11.2\%), Europe (6.1\%), China $(5.9 \%)$ and Singapore $(5.1 \%)$.

The throughput of Keelung port's outward transshipment is about 52 thousand TEU, among them $21.9 \%$ to Philippine, $15.3 \%$ to Japan, $11.7 \%$ to other areas of Asia, $10.0 \%$ to Korea, $7.6 \%$ to Hong Kong and $6.2 \%$ to Oceania. It indicates the major outward transshipment regions for Keelung port is to Far East areas and falls into North/South trade transshipment.

The throughput of Taichung port's outward transshipment is about 131 thousand TEU, among them $36.3 \%$ to Japan, $14.8 \%$ to Middle East, $12.8 \%$ to Malaysia, $8.3 \%$ to Indonesia, $6.4 \%$ to other areas of Asia, 5.8\% to Hong Kong and 5.3\% to Thailand. It indicates Taichung port falls into North/South trade transshipment the same as Keelung Port.

The throughput of Kaohsiung port's outward transshipment is about 2,139 thousand TEU, mainly to North American (34.4\%), Philippine (11.5\%), Japan (10.15\%), Europe $(6.2 \%)$, China $(6.2 \%)$, Singapore $(5.3 \%)$. The statistic data shows that despite the Far East and Southeast Asia regions, Kaohsiung port also transships containers to Europe and North America regions. It indicates that Kaohsiung is a very import transshipment center for Asia-Pacific region.

(3) Origin/Destination of transshipment

The front three origin/destination regions for the whole Taiwan transshipment are China (Minjiang area) $\rightarrow$ Taiwan $\rightarrow$ North American with 156.9 thousand TEU, Thailand $\rightarrow$ Taiwan $\rightarrow$ North American with 127.4 thousand TEU, Philippine $\rightarrow$ Taiwan $\rightarrow$ North American with 124.5 thousand TEU.

The front three origin/destination regions for Keelung port transshipment are Japan $\rightarrow$ Keelung $\rightarrow$ Philippine with 5.6 thousand TEU, other areas in Asia $\rightarrow$ Keelung $\rightarrow$ Korea with 3.7 thousand TEU, Korea $\rightarrow$ Keelung $\rightarrow$ Philippine with 3.5 thousand TEU.

The front three origin/destination regions for Taichung 


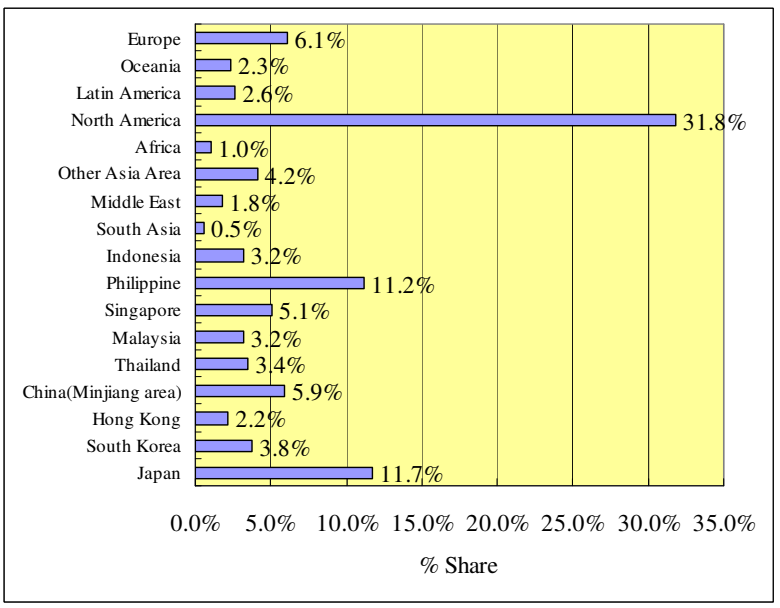

Fig. 4. Taiwan container throughput of outward transshipment to each region (2005).

port transshipment are Indonesia $\rightarrow$ Taichung $\rightarrow$ Japan with 30.2 thousand TEU, Japan $\rightarrow$ Taichung $\rightarrow$ Malaysia with 15.2 thousand TEU, Japan $\rightarrow$ Taichung $\rightarrow$ Middle Ease with 14.7 thousand TEU.

The front three origin/destination regions for Kaohsiung port transshipment are China (Minjiang area) $\rightarrow$ Kaohsiung $\rightarrow$ North American with 156.9 thousand TEU, Thailand $\rightarrow$ Kaohsiung $\rightarrow$ North American with 127.3 thousand TEU, Philippine $\rightarrow$ Kaohsiung $\rightarrow$ North American with 123.2 thousand TEU.

\section{Computation data}

There are two different groups of computation data, namely: maritime costs and port data, as shown in Table 2 and Table 3. Because different parameters have different scales, by applying the formulas (17) and (18), these parameters can be normalized into the scale between 0 and 1. After that these parameters' value can be introduced into PTC model to perform the calculation.

In the transshipment port there are many strengths and weaknesses utility value factors, in this paper following key factors are introduced: number of deep-water berths (over 14m) $\left(I_{1}\right)$, number of container quay cranes $\left(I_{2}\right)$, container terminals area $\left(I_{3}\right)$, external link transportation strength and weakness $\left(I_{4}\right)$, handled automation and information $\left(I_{5}\right)$, efficiency of vessels incoming/outgoing $\left(I_{6}\right)$, efficiency of handling containers $\left(I_{7}\right)$, number of containers handled $\left(I_{8}\right)$, operational liberalization $\left(I_{9}\right)$, integral investment plan $\left(I_{10}\right)$, and efficiency of investment exploitation $\left(I_{11}\right)$. And for the opportunity and threat utility value following key factors are introduced: efficiency of customs service $\left(E_{1}\right)$, political stability $\left(E_{2}\right)$, complete statute $\left(E_{3}\right)$, financial liberalization $\left(E_{4}\right)$, cargo source of the hinterland $\left(E_{5}\right)$, strength and weakness of geographic location $\left(E_{6}\right)$, and number of shipping lines and sailing
Table 2. The normalized maritime cost.

\begin{tabular}{l|c|c|c}
\hline & Keelung & Taichung & Kaohsiung \\
\hline Japan & 1.00 & 0.92 & 0.85 \\
\hline South Korea & 1.00 & 0.87 & 0.78 \\
\hline Hong Kong & 0.72 & 0.94 & 1.00 \\
\hline China (Minjiang area) & 0.56 & 1.00 & 0.77 \\
\hline Thailand & 0.90 & 0.94 & 1.00 \\
\hline Malaysia & 0.90 & 0.95 & 1.00 \\
\hline Singapore & 0.89 & 0.94 & 1.00 \\
\hline Philippine & 0.75 & 0.82 & 1.00 \\
\hline Indonesia & 0.91 & 0.95 & 1.00 \\
\hline South Asia & 0.94 & 0.97 & 1.00 \\
\hline Middle East & 0.96 & 0.98 & 1.00 \\
\hline Other Asia Area & 0.94 & 0.97 & 1.00 \\
\hline Africa & 0.89 & 0.90 & 1.00 \\
\hline North America & 0.93 & 0.92 & 1.00 \\
\hline Latin America & 0.93 & 0.91 & 1.00 \\
\hline Oceania & 0.88 & 0.90 & 1.00 \\
\hline Europe & 0.89 & 0.90 & 1.00 \\
\hline & & & \\
\hline
\end{tabular}

Table 3. The normalized port data.

\begin{tabular}{l|c|c|c}
\hline & Keelung & Taichung & Kaohsiung \\
\hline Port cost utility value & 0.88 & 0.98 & 1.00 \\
\hline SW utility value & 0.56 & 0.61 & 0.91 \\
\hline OT utility value & 0.91 & 0.89 & 1.00 \\
\hline
\end{tabular}

$\left(E_{7}\right)$.

\section{Computation data}

Applied the above data into PTC model, the model validity can be examined. Following are the calculation results:

(1) Estimation of transship containers volume for each port

Fig. 5 shows the observed and computed volume of transship containers for each port in Taiwan. Compared these results with Taiwan total transshipment volume, the difference for each port is less than $2 \%$. For example, the observed transshipment volume for Keelung port is 110.9 thousand TEU (2.1\% of Taiwan transship volume), the computed result is 53.1 thousand TEU (1.0\% of Taiwan transship volume) and the difference is about $-1.1 \%$. The observed volume for Taichung port is 316.2 thousand TEU $(6.0 \%)$; the computed result is 348.1 thousand TEU $(6.6 \%)$ and the difference is $+0.6 \%$. The observed volume for Kaohsiung port is $4,817.0$ thousand TEU (91.9\%); the computed result is $4,862.6$ thousand TEU $(92.4 \%)$ and the difference is $+0.5 \%$.

(2) Occupancy rate for port service regions

Fig. 6 shows the comparison of the observed and the computed throughput of Taiwan inward transship container 


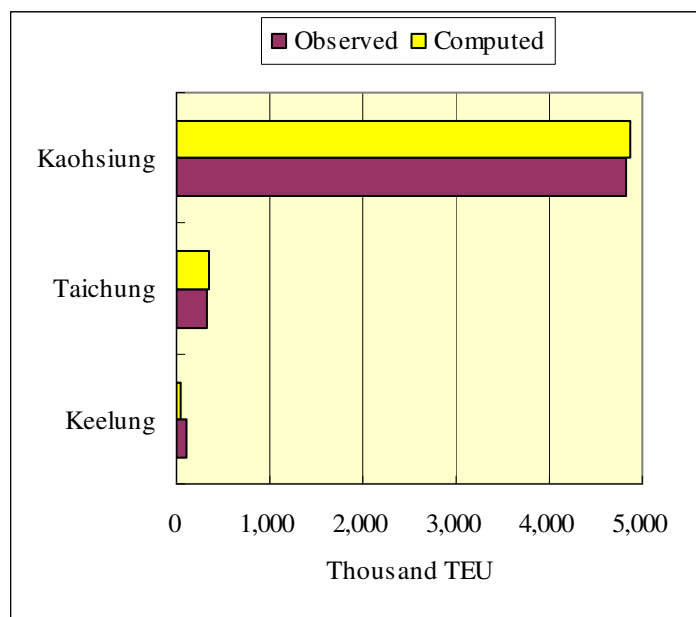

Fig. 5. Comparison of observed \& computed transshipment container volume for Taiwan ports in 2005 .

by 17 regions. For Taichung port, the containers from Middle East, Indonesia and Hong Kong have $+10 \%$ +20\% difference and Malaysia has $-10 \%$ difference with observed data. For Kaohsiung port, the difference of containers from above regions have the same magnitude but with opposite sign. And for all other regions the computed date are dovetailed very well with the observed data.

Most mismatch area is in Asia region, and after further exploring found that for Keelung and Taichung port there are opportunities to compete in the North/South trade especially in between Northeastern Asia and Southeastern Asia. However, in practical Kaohsiung have the better attractive conditions, and consider the short sea and oceangoing routes bonding, ship liners will prefer to concentrate their transshipment container in Kaohsiung port.

\section{CONCLUSION}

The paper proposed a model to evaluate the transshipment port competition, which combining the quantified SWOT method and integer programming method, to explain the competition in container transshipment. After applied PTC model in the container transshipment case study of Taiwan international ports, it is found that the ports' transshipment volume computed from the model is very closed to the observed volume. It can say that this model has the good ability to explain the situations. Although this model can not explain each port's transshipment distribution in detail, but the results matched most situations. Further examined the model results found the most mismatch area is in Asia region. The reason is that although there are opportunities for Keelung and Taichung port to compete the North/South trade in between Northeastern and Southeastern Asia, but in practical Kaohsiung has better attractive conditions, and for bonding the branch routes and trunk routes, carriers will prefer to concentrate their transshipment container in Kaohsiung port.

Taiwan occupies an important position in the national mari- time market, for example, the hinge of main routes and the apical of Pendulum Service route in between Asia-Pacific and North American regions, and the branch routes and trunk routes connection and domestic import/export trading volume. Right now Kaohsiung port is playing the hub port role for Taiwan, however, in the near future Taipei port will joint the competition, and the Shanghai port, Shenzhen port and Xiamen port will all influence Kaohsiung role as a hub port, and their influence can also be studied by the PTC model.

\section{ACKNOWLEDGEMENT}

The authors would like to thank Institute of Transportation Ministry of Transportation and Communications for its support of the research MOTC-IOT-95- H1DB003. The content of this paper is part of the results from that study.

\section{REFERENCES}

1. Ashar, A., "Revolution Now," Containerisation International January 2002, Informa, London, pp. 56-59 (2002).

2. Bendall, H. B. and Stent, A. F., "A Scheduling Model for a High Speed Containership Service: A Hub and Spoke Short-Sea Application," Int. J. Marit. Econ., Vol. 3, pp. 262-277 (2001).

3. Chang, H. H. and Huang, W. C., "Application of a Quantification SWOT Analytical Method," Mathematical and Computer Modelling, Vol. 43, No. 1-2, pp. 158-169 (2006).

4. Deng, J., Grey System Theory and Application, Geo-Li Publishing, Taipei (2000). (in Chinese)

5. Drewry Shipping Consultants Ltd., Annual Container Market Review \& Forecast 2005/06, London (2006).

6. Experian Ltd., Hong Kong Shipping Statistics CD-Rom 2006 Quarter 1, Hong Kong (2006).

7. Hsieh, S. H. and Wong, H. L., "The Marine Single Assignment Nonstrict Hub Location Problem: Formulations and Experimental Examples," J. Mar. Sci. Technol., Vol. 12, No. 4, pp. 343-353 (2004).

8. Hsu, C. I. and Hsieh, Y. P., "Direct Versus Terminal Routing on a Maritime Hub-and-Spoke Container Network," J. Mar. Sci. Technol., Vol. 13, No. 3, pp. 209-217 (2005).

9. Huang, M. J., Huang, W. C., Teng, J. Y., and Wu, S. C., "Ports Competitiveness Evaluation - Case Study of Eastern Asian Container Ports," Proceedings of Eastern Asia Society for Transportation Studies, pp. 24-27 (2001).

10. Huang, M. J., Huang, W. C., Teng, J. Y., and Wu, S. C., "Competitiveness Evaluation for Eastern Asian Container Orts by Using Grey Relational Analysis Method," J. Grey Syst., Vol. 14, No. 3, pp. 139-50 (2002).

11. Huang, W. C., Teng, J. Y., Huang, M. J., and Kou, M. S., "Port Competitiveness Evaluation by Fuzzy Multicriteria Grade Classification Model," $J$. Mar. Sci. Technol., Vol. 11, No. 1, pp. 53-60 (2003).

12. Informa UK Ltd., Containerisation International March 2006, London (2006).

13. Kuroda, K. and Yang, Z., "Stackelberg Equilibria Analysis Container Cargo Behavior," Journal of the Eastern Asia Society for Transportation Studies, Vol. 1, No. 1, pp. 249-261 (1995).

14. Mourão, M. C., Pato, M. V., and Paixão, A. C., "Ship Assignment with Hub and Spoke Constraints," Marit. Policy Manage., Vol. 29, No. 2, pp. 135-150 (2002).

15. O’Kelly, M. E., “A Quadratic Integer Program for the Location of Interacting Hub Facilities,” Eur. J. Oper. Res., Vol. 32, pp. 393-404 (1987).

16. O'Kelly, M. E., “A Geographer's Analysis of Hub-and-Spoke Networks,” J. Transp. Geogr., Vol. 6, No. 3, pp. 171-186 (1998).

17. Robinson, R., "Asian Hub/Feeder Nets: The Dynamics of Restructuring," Marit. Policy Manage., Vol. 25, No.1, pp. 21-40 (1998).

18. Saaty T. L. and Vargas, L. G., Models, Methods, Concepts \& Applications of the Analytic Hierarchy Process, Kluwer Academic Publishers, Boston (1990). 


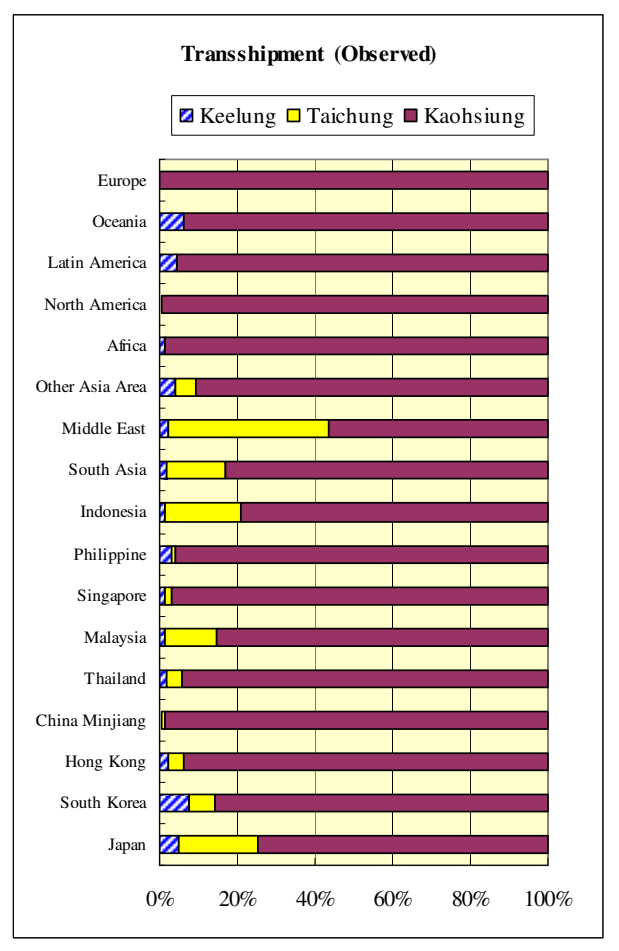

(1) Observed

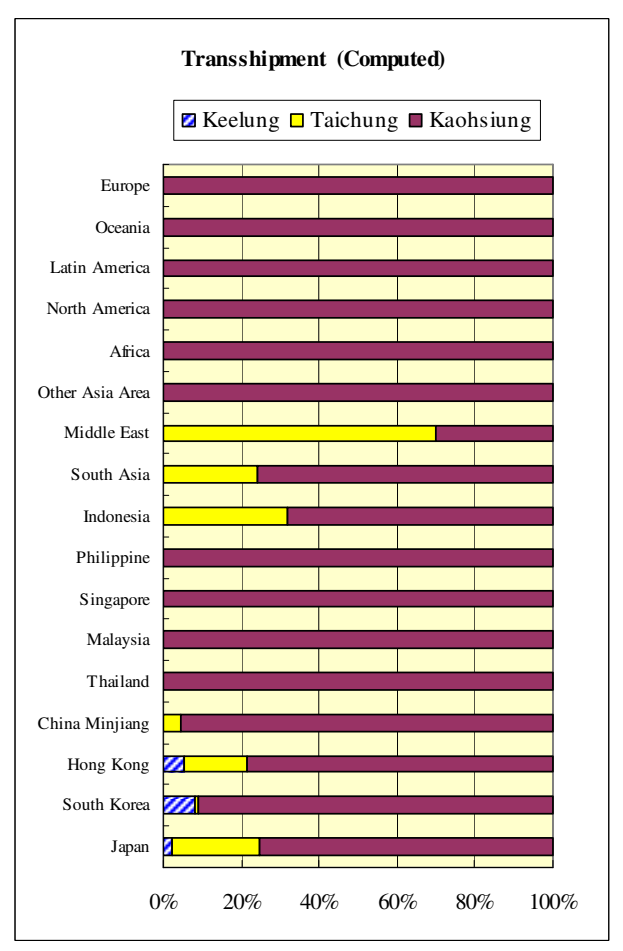

(2) Computed

Fig. 6. Throughput of Taiwan container transshipment by region (2005). 